\title{
CTAG1B wt Allele
}

National Cancer Institute

\section{Source}

National Cancer Institute. CTAG1B wt Allele. NCI Thesaurus. Code C54412.

Human CTAG1B wild-type allele is located in the vicinity of Xq28 and is approximately $2 \mathrm{~kb}$ in length. This allele, which encodes cancer/testis antigen 1B protein, may play a role in both germ cell maturation and immune responsiveness. Aberrant expression of the gene is associated with many cancers. 